\title{
Sickness absence at the French National Electric and Gas Company
}

\author{
A CHEVAliER, D LUCE, ${ }^{1}$ C BLANC, M GOLDBERG ${ }^{1}$
}

From Groupe d'Etude et de Recherche sur les Systèmes de Santé (GERSS), ${ }^{1}$ INSERM U88, 75634 Paris Cedex 13, and Electricité et Gaz de France-Service Général de Médecine de Contrôle, ${ }^{2} 75382$ Paris Cedex 08, France

ABSTRACT The certified sickness absence of workers in the French National Electric and Gas Company was studied for 12 months and has been described according to the demographic and occupational characteristics of the employees. The results showed that the principal factors affecting absence are sex, job, and salary. The high percentage of absent women was explained by neither the type of occupation nor family status. Respiratory diseases, accidents, and musculoskeletal and psychiatric disorders were the leading diagnostic categories. Indices of severity, duration, and frequency were calculated and compared between groups. The duration of absence increased with the severity of the medical cause of absence and with the patient's age.

Many studies on absenteeism have been published as may be seen from several reviews. ${ }^{1-4}$ The economic, psychological, and sociological consequences of work related absenteeism, in particular, have been investigated. Briefly, two lines of research into this problem may be distinguished.

(1) The functionalistic approach considers employee absence as deviant behaviour, the result of poor working conditions, which may adversely affect the worker's health, or as the result of worker dissatisfaction due to fragmented and unrewarding tasks. Absenteeism thus reflects company performance or represents a social malaise.

(2) The analytical approach, where worker absenteeism is seen as a manifestation of social conflict between workers and their employers, and which is sometimes compared with another outward demonstration of discontent, the strike.

When these studies are examined what is obvious is that the "health" dimension is almost completely missing, whereas at least three quarters of employee absences are for health related reasons. Although most companies record data on worker absenteeism, it is quite rare to find medical explanations that correspond to these periods of absence. In the United States several companies have set up systems to collect information on occupational hazards in the workplace, the health status of company employees, and medically related absenteeism. ${ }^{5}$ The "Service Général de Médecine de Contrôle" ("SGMC"),

Accepted 28 May 1986 which is the social security department of the French National Electric and Gas Company has established a comparable data base. The starting point used here was the premise that illness is a factor responsible for employee absences. The objectives of the data base thus are to understand the health status of the worker population, to define relations between employee absenteeism and morbidity better, and to set up methods of research and prevention.

In the present paper we make a preliminary assessment of the medically related worker absenteeism at the French National Electric and Gas Company, and we investigate those factors related to absenteeism, the different aspects concerned, and the medically related reasons for it.

\section{Material and methods}

CHARACTERISTICS OF THE COMPANY

The French Electric and Gas Company is a state owned company whose function is to produce, transport, and distribute energy in the form of electricity and gas. In 1980 when this investigation was conducted, the company employed about 135000 French salaried personnel ( $80 \%$ men). The areas of employment are quite varied ranging from research activity to manual occupations, with a few particular fields such as the production of nuclear energy, important research departments, and highly developed, computerised departments. Employees begin their career in this company between ages 16 and 30 and retirement is set at age 55 for manual workers and age 60 for 
other personnel. In most cases workers spend their entire professional career with this company; thus this a stable population.

The Service Général de Médecine de Contrôle (SGMC) includes about 110 consulting physicians who are assigned throughout all of France.

DA T A

The data base set up by the SGMC in 1975 has been fully operational since 1978 . It records, quite thoroughly, information on all the health care problems of company personnel (sickness absences for short or long periods, work accidents and occupational diseases, worker disability, and death while on the job) as well as data to describe the principal demographic, socioeconomic, and occupational characteristics of all employees. The network for collecting data, the content, and the mode of operation of the data base have been described in detail elsewhere. ${ }^{6}$

The present study concerns short, medically related worker absenteeism in 1980, including all spells of absence for medical reasons whose length was less than one year, and absences of from one to three days. An original aspect of this particular division of the social security system at the Electric and Gas Company is that, theoretically, there is compulsory verification of any certified spell of absence; this makes it possible to establish a diagnosis for the illness which led to the absence each time it occurs. The data and duration of absence are also known ("medical" duration, including weekends). A second category of information includes demographic data: sex, age, family status, and socioeconomic and occupational data: level of education, position held, salary category, duration of company service, geographical locality, and, finally, the notion of a hazardous to health occupation corresponding to positions that present specific health hazards.
The medically related causes for worker spells of absence are classified by the consulting physicians according to a list that includes 176 items, derived from the International Classification of Diseases (8th).

The demographic, socioeconomic, and occupational data are also recorded for all salaried personnel, thereby enabling the determination of various rates.

Absenteeism may be evaluated in several different ways according to its duration or frequency, individually, or within a given population. In the present study we have chosen the individual method of assessment, which alone makes it possible to understand the mechanisms responsible for worker absence. The population of employees affected will be described, firstly, using the percentage of persons who were is absent from work at least once during the year as a measure ("per cent disabled a year"). This index may 오 be considered as an "annual incidence rate" of absence. Its relation with each of the factors for demographic, socioeconomic, and occupational envi- T ronment will be tested using the $\chi^{2}$ statistical test. The $\frac{\mathbb{0}}{2}$ investigation of regional differences will be explored in greater detail by an indirect standardisation, ${ }^{7}=$ which makes it possible to verify the presence of a $\overrightarrow{0}$ "regional effect," since other factors are taken to be constant.

Then the different forms of medically relate worker absence will be studied using two indexes: the number of spells of absence and the number of days lost a year, calculated for each absentee. The two components of absenteeism that they measurenamely, frequency and duration-will be analysed according to the same demographic and occupational factors as in the first part of this study. The statistical methods used here will be principally analyses of variance. Finally, the list of medical diagnoses which explain the absence will be considered.

Table 1 Measures of sickness absenteeism by sex and age

\begin{tabular}{|c|c|c|c|c|c|}
\hline Variable & $\%$ Disabled a year & No of workers & $\chi^{2}$ Test & $\begin{array}{l}\text { Annual duration of absence } \\
\text { (days) }\end{array}$ & $\begin{array}{l}\text { Anmual No of spells } \\
\text { of absence }\end{array}$ \\
\hline \multicolumn{6}{|l|}{ Sex: } \\
\hline $\begin{array}{l}\text { Male } \\
\text { Female }\end{array}$ & $\begin{array}{l}43 \cdot 7 \\
65 \cdot 2\end{array}$ & $\begin{array}{r}111837 \\
23462\end{array}$ & $\begin{array}{l}3.590 \\
p<0.001\end{array}$ & $\begin{array}{l}28.9 \\
36.1 \\
F: 258.33 \\
p<0.001\end{array}$ & $\begin{array}{l}1.67 \\
2.02 \\
\text { F: } 1.073 \\
p<0.001\end{array}$ \\
\hline $\begin{array}{c}\text { Age (years): } \\
\leqslant 20 \\
21-25 \\
26-30 \\
31-35 \\
36-40 \\
41-45 \\
46-50 \\
51-55 \\
\geqslant 56\end{array}$ & $\begin{array}{l}42 \cdot 0 \\
48 \cdot 4 \\
51 \cdot 2 \\
48 \cdot 5 \\
43 \cdot 7 \\
42 \cdot 4 \\
44 \cdot 6 \\
51 \cdot 5 \\
55 \cdot 0\end{array}$ & $\begin{array}{r}2043 \\
17063 \\
22570 \\
22069 \\
16833 \\
17131 \\
18376 \\
15967 \\
3 \cdot 247\end{array}$ & $\begin{array}{l}672.3 \\
p<0.001\end{array}$ & $\begin{array}{l}17 \cdot 9 \\
20 \cdot 79 \\
22 \cdot 77 \\
25 \cdot 6 \\
27 \cdot 9 \\
31 \cdot 7 \\
39 \cdot 23 \\
47 \cdot 8 \\
51 \cdot 3 \\
\text { F: } 318 \cdot 9 \\
\text { p }<0.001\end{array}$ & $\begin{array}{l}1.64 \\
1.71 \\
1.75 \\
1.74 \\
1.73 \\
1.73 \\
1.81 \\
1.81 \\
1.70 \\
\text { F: } 9.068 \\
\text { p }<0.001\end{array}$ \\
\hline
\end{tabular}




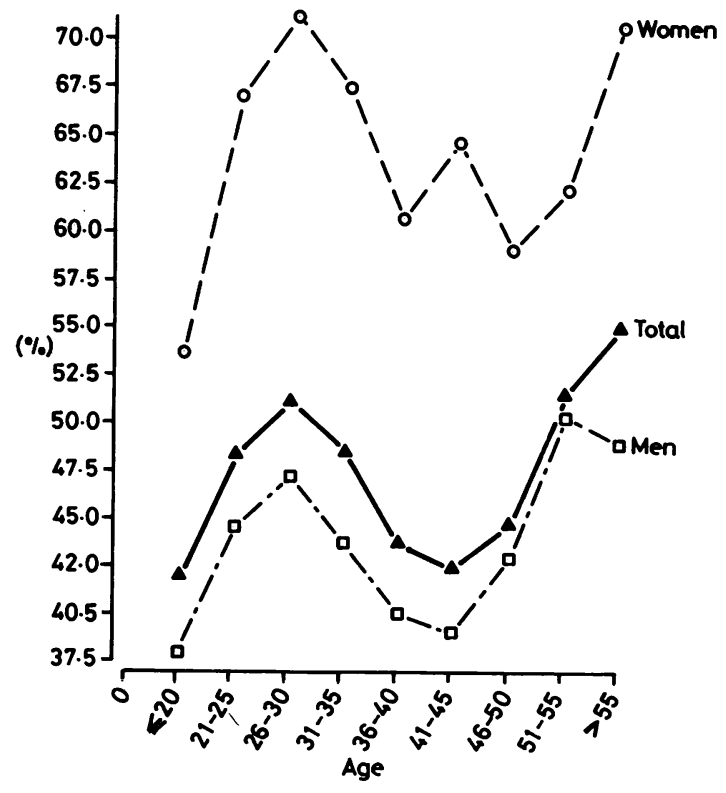

Fig 1 Percentage of disabled per year by age.

\section{Results}

THE ABSENT EMPLOYEE-WHO IS HE?

Half of the 135000 workers employed by the company in 1980 were absent from work at least once for a medically related reason. This percentage varied greatly according to different factors considered.

Demographic factors: sex, age (table 1)

The different aspects of absenteeism according to whether the employees are male or female are important. The proportion of female employees on leave during the course of a year is $65.3 \%$. For male

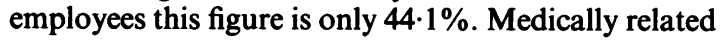
absence thus affects many women.
Since these are medically related absences, a curve representing the proportion of absentees might have been expected to increase with individual age. This is not so (fig 1). The curve presents a concave aspect as represented by the 36-45 years old category. This trend is similar for both men and women.

\section{Family status}

Family status is conditioned by two variables: the marital status and the number of dependent children (table 2). The proportion of absentees varies significantly according to marital status. Widowed, separated, or divorced employees are most frequently absent from work, whether male or female. This result is unchanged when age is also considered. This fact has been reported by others ${ }^{8}$ and may be compared with similar findings noted in studies of mortality rates both in the National Electric and Gas Company, in France as a whole, and in developed countries. $^{9-12}$

The rate of absentees does not seem to be related, overall, to the presence of dependent children. For women, however, a different result is to be noted (fig 2): the proportion of women who are absent from their jobs increases with an increasing number of dependent children, from $60.8 \%$ (no children) to $72.4 \%$ (four or more children). A medical explanation may be given for these results: important family responsibilities cause excessive fatigue requiring subsequent recuperation and absence from work. Another explanation may be absence because of the need to care for a sick child. Although spells of absence are given to female employees to care for sick children, medically related absenteeism studied here probably includes a few instances of this type.

\section{Social and occupational factors}

The social and occupational status of company employees was investigated by means of four variables: salary category, which corresponds to the level of job responsibility, the position held, the notion of a

Table 2 Measures of sickness absenteeism according to family status

\begin{tabular}{|c|c|c|c|c|c|}
\hline Variable & $\%$ Disabled a year & No of workers & $\chi^{2}$ Test & $\begin{array}{l}\text { Annual duration of absence } \\
\text { (days) }\end{array}$ & $\begin{array}{l}\text { Annual No of spells } \\
\text { of absence }\end{array}$ \\
\hline \multirow[t]{2}{*}{$\begin{array}{l}\text { Marital status: } \\
\text { Unmarried } \\
\text { Married } \\
\text { Widowed, separated, } \\
\text { or divorced }\end{array}$} & $\begin{array}{l}45 \cdot 5 \\
47 \cdot 1 \\
67 \cdot 4\end{array}$ & $\begin{array}{r}18380 \\
111321 \\
5598\end{array}$ & $\begin{array}{l}470.33 \\
\mathrm{p}<0.001\end{array}$ & $\begin{array}{l}26 \cdot 3 \\
30 \cdot 3 \\
46 \cdot 45\end{array}$ & $\begin{array}{l}1.73 \\
1.73 \\
2.1\end{array}$ \\
\hline & & & & $\begin{array}{l}\text { F: } 214.7 \\
\text { p }<0.001\end{array}$ & $\begin{array}{l}\text { F: } 165.48 \\
\text { p }<0.001\end{array}$ \\
\hline $\begin{array}{l}\text { Dependent children: } \\
\quad 0 \\
\geqslant 1\end{array}$ & $\begin{array}{l}47 \cdot 2 \\
47 \cdot 6\end{array}$ & $\begin{array}{l}52586 \\
82713\end{array}$ & $\mathrm{NS}^{1.66}$ & $\begin{array}{l}34 \cdot 19 \\
28 \cdot 4 \\
F: 219 \cdot 2 \\
p<0 \cdot 001\end{array}$ & $\begin{array}{l}1 \cdot 78 \\
1.74 \\
F: 18.4 \\
p<0.001\end{array}$ \\
\hline
\end{tabular}




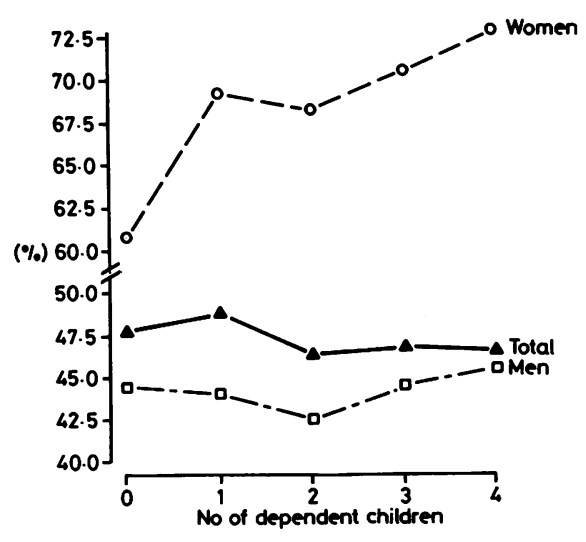

Fig 2 Percentage of disabled per year by number of dependent children.

hazardous occupation, and, finally, duration of employment in the company.

The probability of an employee being absent during the year for a medically related reason is greatly affected by his occupational category. In the lowest categories this likelihood is more than double that of managerial personnel, with foremen being intermediate in this order (table 3). This order is the same for both men and women (fig 3).

The position held also plays an important part. The classification used includes 25 different headings corresponding to different occupations. Between the occupation most prone to absence, that of "switchboard operator," and the one least exposed "skilled technician and upper management" the ratio for the proportions of employees absent from each category is $4 \cdot 7$. The highest numbers of absences are observed for secretaries, typists, and switchboard operators, occupations held principally by women, and janitors and security guards, who have been reassigned generally for reasons of health. Manual workers are generally more frequently affected than sedentary employees.

The notion of a hazardous to health occupation is specific for the company. These are positions which have been found to be dangerous to health, either because of the type of work or because of environmental conditions (noise, pollution, heat, ... (table 4).

Table 3 Measures of sickness absenteeism according to occupational parameters (salary category and occupation)

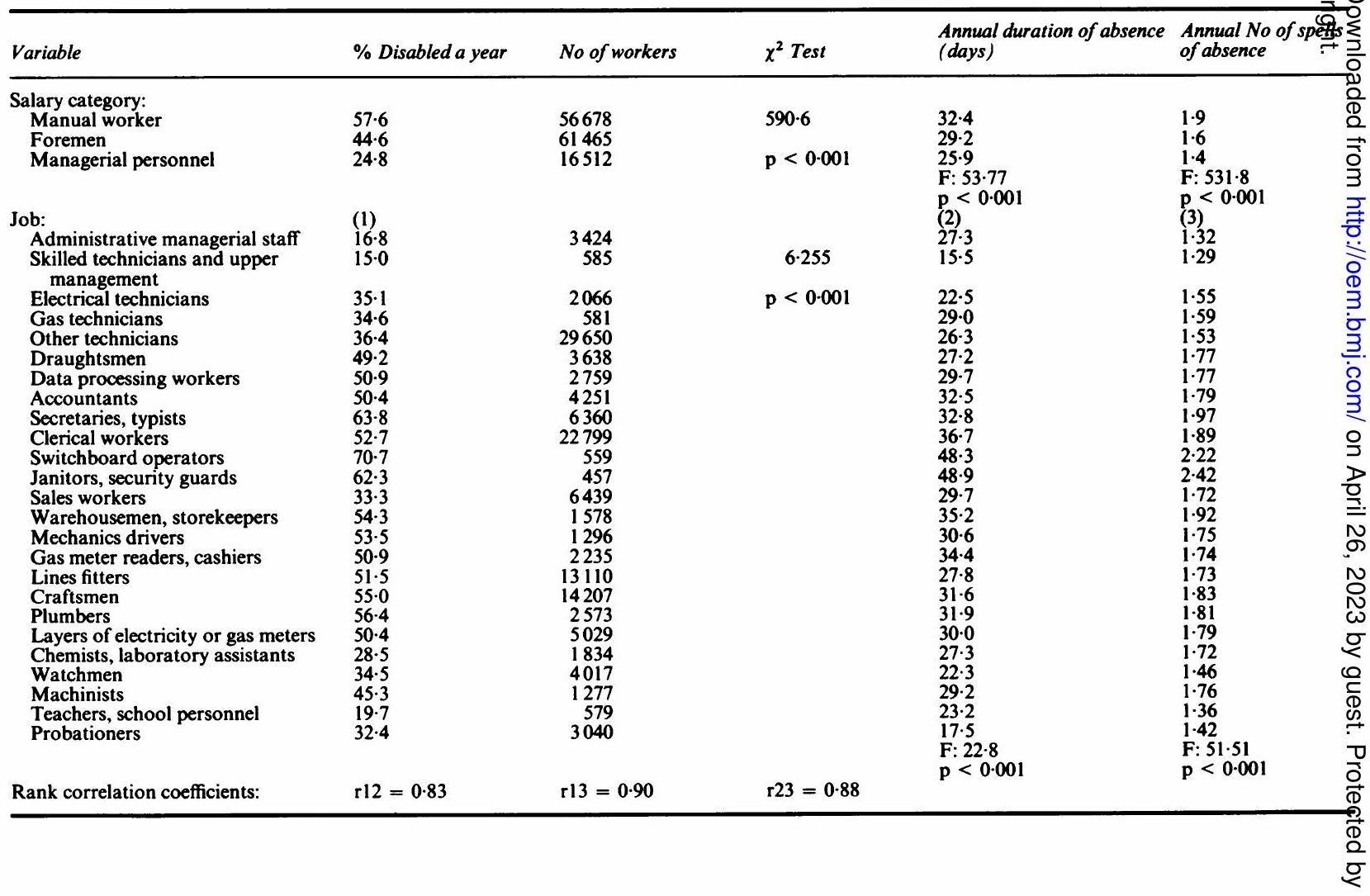




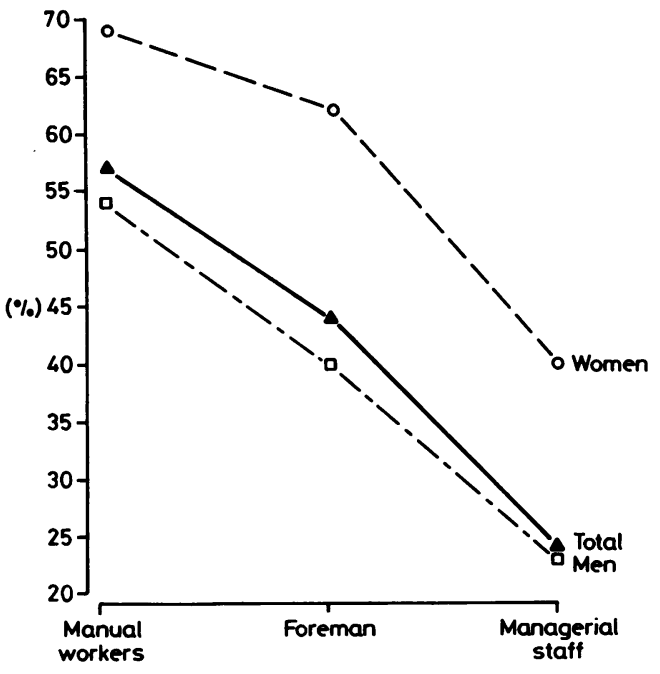

Fig 3 Percentage of disabled per year by salary category.

It is to be noted that employees who perform jobs hazardous to health are more frequently absent from work than other personnel. Since seniority in hazardous occupations was not known here, it is difficult to interpret this result.

Finally, variations in the percentage of absent employees according to their seniority in the company were considered (table 4): this index decreases significantly as seniority increases, ranging from $55.7 \%$ for employees recently hired to $41.6 \%$ for those employed more than 20 years with the company.

\section{Geographic region}

Geography was considered, with company employees being dispersed throughout France. We chose the classification of the INSEE (French National Institute for Statistics). Most studies on absenteeism show

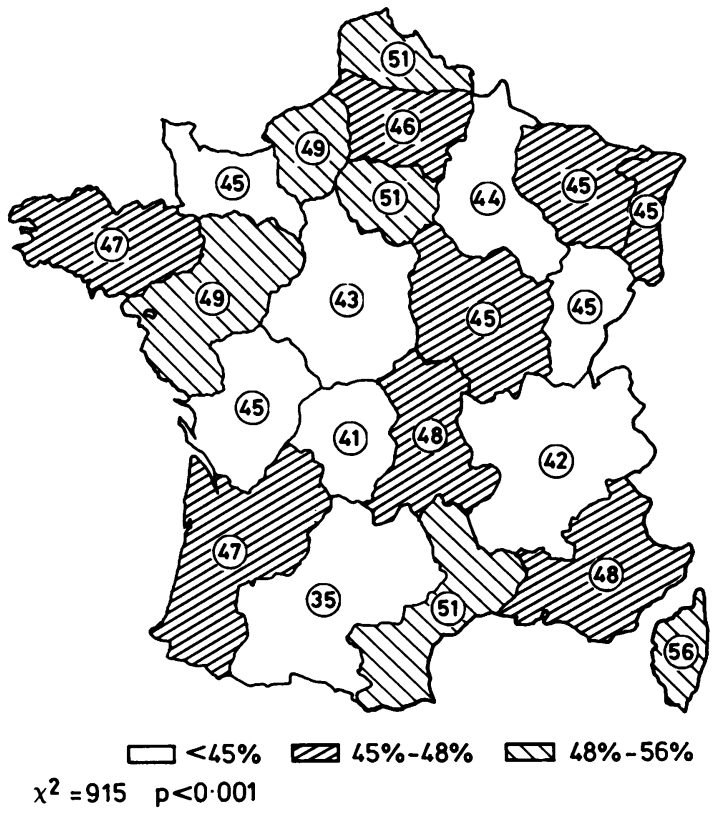

Fig 4 Percentage of disabled per year according to the work place (INSEE regions).

wide geographical differences. The same is true for the National Electric and Gas Company. Between extreme values reported in Corsica and the MidiPyrénées region, the ratio for the percentage of absent employees is $1 \cdot 6$. Examination of fig 4 does not show the existence of a gradient.

The factors previously examined (age, sex ...) have unequal distributions according to different geographical regions. It might be concluded that regional differences observed for medically related absences are due to such differences. To verify this, standardisation was performed for age, sex, and job category: differences due to geographical region persist, in the

Table 4 Measures of sickness absenteeism according to occupational parameters (hazardous occupation and seniority)

\begin{tabular}{|c|c|c|c|c|c|}
\hline Variable & $\%$ Disabled a year & No of workers & $\chi^{2}$ Test & $\begin{array}{l}\text { Annual duration of absence } \\
\text { (days) }\end{array}$ & $\begin{array}{l}\text { Annual No of spells } \\
\text { of absence }\end{array}$ \\
\hline \multicolumn{6}{|c|}{ Hazardous occupation: } \\
\hline $\begin{array}{l}\text { Yes } \\
\text { No }\end{array}$ & $\begin{array}{l}59 \cdot 0 \\
47 \cdot 3\end{array}$ & $\begin{array}{r}1900 \\
133399\end{array}$ & $\begin{array}{l}103.9 \\
p<0.001\end{array}$ & $\begin{array}{l}32 \cdot 6 \\
30 \cdot 5 \\
\text { F: } 1 \cdot 97 \\
\text { NS }\end{array}$ & $\begin{array}{l}1.89 \\
1.77 \\
\text { F: } 16.26 \\
\text { p }<0.001\end{array}$ \\
\hline \multicolumn{6}{|c|}{ Seniority in company (years): } \\
\hline $\begin{array}{l}<5 \\
5-9 \\
i j-19 \\
\geqslant 20\end{array}$ & $\begin{array}{l}55 \cdot 7 \\
53 \cdot 2 \\
46 \cdot 8 \\
41 \cdot 6\end{array}$ & $\begin{array}{l}24147 \\
20523 \\
41222 \\
49407\end{array}$ & $\begin{array}{l}1613.96 \\
p<0.001\end{array}$ & $\begin{array}{l}21 \cdot 0 \\
25 \cdot 2 \\
29 \cdot 5 \\
40 \cdot 9 \\
\text { F: } 543 \cdot 19 \\
p<0.001\end{array}$ & $\begin{array}{l}1.67 \\
1.82 \\
1.77 \\
1.75 \\
\text { F: } 36.16 \\
\text { p }<0.001\end{array}$ \\
\hline
\end{tabular}


same direction as previously observed. It thus appears that there is a "regional effect," which may be either specific for the company or due to general, socioeconomic, and cultural conditions. An investigation involving geographic differences for health status was undertaken at the National Electric and Gas Company to attempt to elucidate the mechanism concerned. ${ }^{13}$

The generalised description of "factors related to employee absenteeism" concurs with what is usually reported. ${ }^{1415}$ This is normal since a medically related reason is the primary cause of worker absence. Several points must be made here: the high rate of absenteeism of women and the part of the occupational category and of the position held. In effect, it was observed that the percentage of absent female employees is always higher than for their male counterparts whatever factors are considered. Except for the number of dependent children, the curves representing rates of male or female absenteeism are entirely analagous. It thus appears that factors usually implicated to explain high rates of female absenteeism (lesser job responsibility, type of work, dependent children, ...), although important, are inadequate to explain the differences observed in the absentee rates for men and women employees. A more detailed investigation considering parameters such as the reasons for working, opportunities for job training and promotion, the sharing of household chores between husband and wife, attitudes towards health, and medically related reasons is necessary to understand this phenomenon better.

Just as important is the variation according to the category of work and the position held. Several different levels of explanation may be considered: for the same disorder, especially if it is a minor one, it is normal that absences are more frequently reported for outdoor workers or for employees whose jobs require considerable physical activity than for office personnel. Moreover, the hazards to healthy vary according to the type of work done. Thus a particular occupational risk, work accident, is eight times more likely to involve driver mechanics than accountants.
Chevalier, Luce, Blanc, Goldberg The particular position held, like the job category, has a socioeconomic significance. Numerous studies, especially in English speaking countries, have shown ?. the existence of relation between different social $\overrightarrow{\bar{B}}$ classes and worker mortality and morbidity. ${ }^{16}$ Social differences for morbidity surface from the data available for medical absenteeism. Finally, explanations which are sociological in their nature must not be forgotten as already mentioned at the beginning of this study.

\section{WHAT ABSENTEEISM?}

Two different measures of employee absenteeism will be described: the duration of the absence and the number of spells of absence a year. An employee who absents himself from his job does so 1.75 times a year, and cumulates 30.6 days of leave, on average. This figure may appear high but, in fact, it is only due to ? lengthy absences by a small number of employees. If $\vec{\circ}$ we look at table 5 it may be noted that absenteeism presents wide individual differences. More than half of the employees are on leave for brief periods (less than 15 days a year). Few people have repeated sickness absences.

Then the two measures characterising employee absence were investigated according to those factors already mentioned. For a large number of these faes $\infty$ tors (sex, job category, occupation, family statusis both indexes vary on the average in the same sense as the proportion of absent employees (tables 1-4). Thus it is those positions most affected by absenteeism which present the most serious cases, both for frequency of absences and for number of days lost (Spearman's rank correlation tests are significant). The same is true for the work category level where, whatever the index used to measure absenteeism, the sequence of "manager, foreman, and manual worker" is always found in that order, family status with the "widowed-separated-divorced" employees being most frequently affected, and, the sex, with the female high rate of absenteeism.

For the other factors studied, age, seniority, hazardous working conditions, and geographical

Table 5 Number of disabled workers according to duration and frequency of annual absence

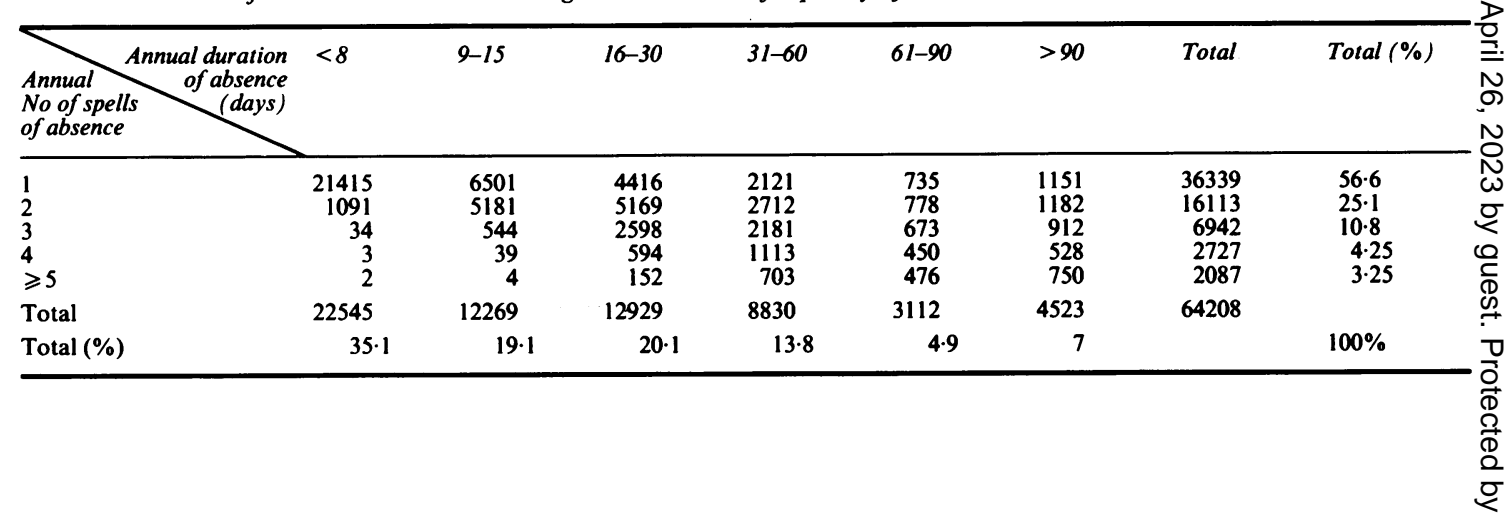


location no correlation was observed. With employee age, a noteworthy fact is the constant increase in the mean duration of absence as age increases. Among employees on leave, those aged 55 have, on average, three times more disability than those who are closer to age 20. The nature of the illness responsible for the absence and a longer recovery time are natural explanations. In the same way, and for the same reasons, an increase in the duration of the absence is observed with seniority in the company. In both cases the mean number of spells of absence a year varies, without being able to find a simple explanation (tables 1 and 4). The hazardous nature of the position held does not seem greatly to affect the characteristics of absenteeism. At most, a slightly increased number of absences may be observed in those employees who have such a position. Finally, a regional study, considering the ages of the employee population using analysis of variance, shows regional differences for the duration of absences a year with longer absences in south east France (Rhône-Alpes, Provence, Côte d'Azur, and Corsica) and the Paris metropolitan area, and shorter ones for Haute Normandie, Brittany, and Central France.

\section{MEDICAL REASONS}

A high number of spells of absence, especially those which are quite short, are not verified by the company physician. The medically related causes thus are unknown in such cases. To evaluate the weight of different disorders in an effective manner, a survey involving 2000 unverified absences was conducted in 1980. Taking this investigation into account, the principal causes of employee absence are, in their order of frequency: respiratory diseases, trauma, osteoarticular disorders, and psychiatric and digestive illnesses (table 6). The order is different if weight is given to the duration of course of each illness: the severity of accidents and the disabling nature of psychiatric and osteoarticular disorders should be emphasised. Each spell of absence lasts 17 days on the average, with large differences according to individual diagnosis.

The effects of age, sex, and of the worker's job category were investigated within each diagnostic group with two overall indexes: the number of spells of absence per 100 employees (frequency rate) and the mean number of days of disability per absence (severity rate).

Age has a certain effect on the severity rate, which increases for all diagnoses considered (table 7). Its effect on the frequency of absence is lesser and does not concern all medical dic.gnoses: the frequency rate increases with the subject's age for osteoarticular and circulatory diseases; it tends to decrease for respiratory disease and for trauma. The frequency rate is always higher for women except for occupationally related accidents (table 6). With female employees, the frequency rate for urogenital disease and psychiatric disorders should be emphasised, as well as the diagnosis of lassitude. On the severity rate, the effect of the subject's sex is variable. For all diag-

Table 6 Measures of sickness absenteeism by diagnostic category

\begin{tabular}{|c|c|c|c|c|c|c|c|}
\hline \multirow[b]{3}{*}{ Diagnostic category } & \multicolumn{3}{|c|}{ Employees absent at least once during the year } & \multicolumn{4}{|c|}{ By sex } \\
\hline & \multirow{2}{*}{$\begin{array}{l}\text { Severity rate } \\
\text { (days) }\end{array}$} & \multirow[t]{2}{*}{$\%$ Of total absence } & \multirow{2}{*}{$\begin{array}{l}\% \text { Of total leaves } \\
\text { (after correction) }\end{array}$} & \multicolumn{2}{|c|}{ Frequency rate } & \multicolumn{2}{|c|}{ Severity rate } \\
\hline & & & & Men & Women & $\overline{M e n}$ & Women \\
\hline Respiratory affections: & $10 \cdot 8$ & $9 \cdot 0$ & $27 \cdot 7$ & 10.9 & 15.9 & $12 \cdot 0$ & $11 \cdot 5$ \\
\hline Influenza & 8.9 & $2 \cdot 3$ & 9.7 & 3.4 & $4 \cdot 6$ & 8.7 & $10 \cdot 0$ \\
\hline Accidents: & $28 \cdot 1$ & $15 \cdot 9$ & $14 \cdot 2$ & 8.6 & 4.8 & $28 \cdot 1$ & $2 \cdot 4$ \\
\hline Accidents at work & $26 \cdot 5$ & $7 \cdot 05$ & $5 \cdot 7$ & $4 \cdot 1$ & $2 \cdot 0$ & $26 \cdot 8$ & $8 \cdot 2$ \\
\hline Other accidents & $29 \cdot 5$ & $8 \cdot 8$ & $8 \cdot 5$ & $4 \cdot 5$ & 2.8 & 29.6 & $2 \cdot 1$ \\
\hline Musculoskeletal disorders & $25 \cdot 1$ & $9 \cdot 2$ & $10 \cdot 5$ & $4 \cdot 9$ & $6 \cdot 1$ & $25 \cdot 4$ & 0.9 \\
\hline Digestive disorders & $22 \cdot 0$ & $5 \cdot 7$ & $7 \cdot 2$ & $3 \cdot 5$ & $4 \cdot 4$ & $24 \cdot 3$ & $1 \cdot 3$ \\
\hline Mental disorders & 35.9 & $9 \cdot 5$ & $7 \cdot 5$ & $2 \cdot 7$ & $8 \cdot 7$ & $38 \cdot 1$ & $9 \cdot 5$ \\
\hline Genitourinary disorders & $29 \cdot 4$ & $5 \cdot 2$ & $4 \cdot 0$ & 0.9 & $9 \cdot 7$ & $23 \cdot 8$ & 3.0 \\
\hline Lassitude & $15 \cdot 3$ & $2 \cdot 0$ & 4.9 & $1 \cdot 2$ & $4 \cdot 9$ & $15 \cdot 1$ & 6.5 \\
\hline Cardiovascular diseases & $44 \cdot 4$ & 5.9 & 3.8 & 1.8 & $2 \cdot 1$ & $45 \cdot 9$ & $6 \cdot 4$ \\
\hline Infectious diseases & $27 \cdot 8$ & $1 \cdot 4$ & - & 0.6 & $1 \cdot 0$ & $29 \cdot 1$ & $24 \cdot 8$ \\
\hline $\begin{array}{l}\text { Diseases of skin and } \\
\text { subcutaneous tissue }\end{array}$ & $16 \cdot 5$ & 0.7 & $1 \cdot 6$ & 0.6 & 0.7 & $17 \cdot 4$ & $18 \cdot 4$ \\
\hline Diseases of sense organs & $24 \cdot 3$ & $1 \cdot 0$ & $1 \cdot 2$ & 0.5 & 0.9 & $25 \cdot 7$ & $3 \cdot 6$ \\
\hline $\begin{array}{l}\text { Endocrine nutritional and } \\
\text { metabolic diseases }\end{array}$ & $29 \cdot 8$ & $1 \cdot 0$ & $1 \cdot 3$ & 0.4 & $0 \cdot 8$ & $28 \cdot 2$ & 44.9 \\
\hline Malignant neoplasms & $109 \cdot 0$ & $2 \cdot 7$ & $1 \cdot 1$ & $0 \cdot 3$ & 0.5 & $99 \cdot 3$ & $105 \cdot 8$ \\
\hline Diseases of nervous system & $39 \cdot 2$ & $1 \cdot 1$ & $1 \cdot 25$ & 0.4 & 0.9 & $41 \cdot 8$ & 43.5 \\
\hline Diseases of blood & $44 \cdot 7$ & $0 \cdot 2$ & 0.8 & - & - & $45 \cdot 2$ & $36 \cdot 3$ \\
\hline Others & $24 \cdot 7$ & $2 \cdot 2$ & 12.95 & $2 \cdot 1$ & 6.9 & $19 \cdot 4$ & 19.6 \\
\hline No diagnosis & 9.6 & $27 \cdot 3$ & - & & - & - & - \\
\hline
\end{tabular}


Table 7 Measures of sickness absenteeism by diagnostic category and age

\begin{tabular}{|c|c|c|c|c|c|c|c|c|}
\hline \multirow[b]{2}{*}{ Diagnostic category } & \multicolumn{4}{|c|}{ Frequency rate } & \multicolumn{4}{|c|}{ Severity rate } \\
\hline & $18-30$ & $31-40$ & $41-50$ & $>50$ & $18-30$ & $31-40$ & $41-50$ & $>50$ \\
\hline Respiratory affections: & $12 \cdot 0$ & $11 \cdot 6$ & $10 \cdot 9$ & $13 \cdot 0$ & $9 \cdot 1$ & $10 \cdot 5$ & $13 \cdot 2$ & $17 \cdot 9$ \\
\hline Influenza & 3.5 & $3 \cdot 7$ & $3 \cdot 5$ & 3.9 & $7 \cdot 8$ & $8 \cdot 1$ & $10 \cdot 1$ & $11 \cdot 2$ \\
\hline Accidents: & 9.7 & $7 \cdot 6$ & 6.9 & $7 \cdot 1$ & $24 \cdot 1$ & $28 \cdot 3$ & 29.8 & $34 \cdot 6$ \\
\hline Accidents at work & $4 \cdot 2$ & 3.4 & 3.6 & 3.9 & $20 \cdot 0$ & $26 \cdot 2$ & 31.4 & 36.9 \\
\hline Other accidents & $5 \cdot 5$ & $4 \cdot 2$ & $3 \cdot 3$ & $3 \cdot 2$ & $26 \cdot 8$ & $28 \cdot 5$ & 32.6 & $39 \cdot 4$ \\
\hline Musculoskeletal disorders & $2 \cdot 2$ & 3.9 & 6.9 & $10 \cdot 8$ & $22 \cdot 0$ & $22 \cdot 0$ & $26 \cdot 0$ & $32 \cdot 0$ \\
\hline Digestive disorders & $3 \cdot 2$ & $3 \cdot 2$ & $5 \cdot 0$ & $5 \cdot 2$ & $16 \cdot 7$ & $21 \cdot 0$ & $26 \cdot 0$ & $31 \cdot 0$ \\
\hline Mental disorders & $2 \cdot 5$ & $4 \cdot 3$ & $4 \cdot 1$ & $4 \cdot 6$ & $30 \cdot 8$ & $34 \cdot 0$ & 40.4 & $51 \cdot 0$ \\
\hline Genitourinary disorders & 3.0 & 2.6 & 1.8 & $2 \cdot 1$ & $28 \cdot 5$ & $31 \cdot 9$ & $28 \cdot 6$ & $32 \cdot 6$ \\
\hline Lassitude & $1 \cdot 7$ & $2 \cdot 0$ & $1 \cdot 7$ & $2 \cdot 3$ & $13 \cdot 0$ & $14 \cdot 6$ & $17 \cdot 8$ & $19 \cdot 3$ \\
\hline Cardiovascular diseases & 0.5 & $1 \cdot 2$ & $2 \cdot 4$ & $5 \cdot 3$ & $20 \cdot 5$ & $27 \cdot 0$ & $45 \cdot 0$ & $54 \cdot 0$ \\
\hline Infectious diseases & 0.9 & $0 . \overline{7}$ & 0.6 & 0.7 & $17 \cdot 0$ & $26 \cdot 4$ & $30 \cdot 5$ & $39 \cdot 5$ \\
\hline $\begin{array}{l}\text { Diseases of skin and } \\
\text { subcutaneous tissue }\end{array}$ & 0.6 & 0.5 & 0.6 & 0.6 & 13.0 & $15 \cdot 0$ & $18 \cdot 0$ & $24 \cdot 4$ \\
\hline Diseases of sense organs & 0.4 & 0.6 & 0.6 & 0.9 & $18 \cdot 7$ & $23 \cdot 0$ & $29 \cdot 3$ & $39 \cdot 0$ \\
\hline $\begin{array}{l}\text { Endocrine nutritional and } \\
\text { metabolic diseases }\end{array}$ & $0 \cdot 2$ & 0.4 & 0.6 & $1 \cdot 0$ & $29 \cdot 0$ & 33.5 & $30 \cdot 0$ & $34 \cdot 4$ \\
\hline Malignant neoplasms & - & $0 \cdot 1$ & 0.6 & 0.9 & $74 \cdot 5$ & $77 \cdot 0$ & $99 \cdot 0$ & $112 \cdot 0$ \\
\hline Diseases of nervous system & $0 \cdot 2$ & 0.3 & 0.6 & 0.6 & $34 \cdot 0$ & $35 \cdot 0$ & $51 \cdot 0$ & 43.0 \\
\hline Diseases of blood & - & - & - & - & $45 \cdot 0$ & $25 \cdot 0$ & $29 \cdot 0$ & $76 \cdot 0$ \\
\hline Others & 0.9 & $1 \cdot 1$ & $1 \cdot 2$ & $1 \cdot 5$ & $14 \cdot 2$ & $18 \cdot 2$ & $21 \cdot 4$ & $26 \cdot 8$ \\
\hline
\end{tabular}

noses, the frequency rate increases in the following order: manager, foreman, manual worker (table 8). No trend has been uncovered concerning mean duration of absence.

This overall study was followed by one conducted on an individual basis ${ }^{17}$ : for each diagnosis, the annual duration of absence and the number of spells of absence per person were determined. Only the preliminary results will be cited from this study: a correspondence between the severity of the condition diagnosed as assessed by the mean duration of absence and as evaluated in the light of medical science. Thus with more than 100 days of absence per employee, $\mathbb{D}$ serious illnesses are found, either because they affect the patient's survival or because they threaten an essential life function-cancers, myocardial infarction, alcoholic cirrhosis, tuberculosis, and cataracts $\cong$

On the other hand, diagnoses which involved mean duration of absence of less than 15 days perf worker are reputed to be minor since recovery is tho most common outcome: sore throats, flu, upper respiratory infections, etc.

The mean number of spells of absence a year varies much less from one diagnosis to another than does

Table 8 Measures of sickness absenteeism by diagnostic category and salary category

\begin{tabular}{|c|c|c|c|c|c|c|}
\hline \multirow[b]{2}{*}{ Diagnostic category } & \multicolumn{3}{|l|}{ Frequency rate } & \multicolumn{3}{|l|}{ Severity rate } \\
\hline & Manual workers & Foremen & Managerial staff & Manual workers & Foremen & Managerial staff \\
\hline Respiratory affections: & 15.9 & $10 \cdot 3$ & $3 \cdot 3$ & $11 \cdot 9$ & $11 \cdot 8$ & $13 \cdot 0$ \\
\hline Influenza & $4 \cdot 9$ & $3 \cdot 2$ & 1.0 & $9 \cdot 2$ & $8 \cdot 7$ & $9 \cdot 7$ \\
\hline Accidents: & $11 \cdot 5$ & $6 \cdot 4$ & $2 \cdot 1$ & $32 \cdot 5$ & $30 \cdot 4$ & $27 \cdot 4$ \\
\hline Accidents at work & $5 \cdot 7$ & $2 \cdot 8$ & 0.8 & $25 \cdot 8$ & $29 \cdot 1$ & $27 \cdot 2$ \\
\hline Other accidents & $5 \cdot 8$ & 3.6 & $1 \cdot 3$ & $29 \cdot 2$ & $30 \cdot 6$ & $32 \cdot 4$ \\
\hline Musculoskeletal disorders & $6 \cdot 7$ & $4 \cdot 7$ & 1.5 & $27 \cdot 4$ & $26 \cdot 7$ & $26 \cdot 4$ \\
\hline Digestive disorders & $4 \cdot 7$ & $3 \cdot 3$ & 1.6 & $23 \cdot 9$ & $22 \cdot 6$ & $29 \cdot 6$ \\
\hline Mental disorders & $4 \cdot 8$ & 3.4 & $1 \cdot 3$ & $38 \cdot 0$ & $39 \cdot 7$ & 36.0 \\
\hline Genitourinary disorders & $3 \cdot 2$ & $2 \cdot 3$ & 0.8 & $29 \cdot 8$ & $30 \cdot 5$ & $27 \cdot 8$ \\
\hline Lassitude & 2.6 & 1.6 & $0 \cdot 5$ & $15 \cdot 6$ & $16 \cdot 1$ & $14 \cdot 1$ \\
\hline Cardiovascular diseases & $2 \cdot 0$ & 1.9 & $1 \cdot 3$ & $42 \cdot 3$ & $43 \cdot 8$ & $52 \cdot 7$ \\
\hline Infectious diseases & 0.9 & 0.7 & 0.3 & $27 \cdot 0$ & $28 \cdot 0$ & $35 \cdot 8$ \\
\hline $\begin{array}{l}\text { Diseases of skin and } \\
\text { subcutaneous tissue }\end{array}$ & $0 \cdot 8$ & 0.5 & $0 \cdot 2$ & $17 \cdot 8$ & $17 \cdot 5$ & 15.8 \\
\hline Diseases of sense organs & 0.7 & 0.6 & $0 \cdot 2$ & $26 \cdot 0$ & $27 \cdot 8$ & $38 \cdot 8$ \\
\hline $\begin{array}{l}\text { Endocrine nutritional and } \\
\text { metabolic diseases }\end{array}$ & 0.6 & 0.4 & $0 \cdot 1$ & $34 \cdot 5$ & $30 \cdot 3$ & $25 \cdot 1$ \\
\hline Malignant neoplasms & $0 \cdot 3$ & 0.3 & 0.4 & 113.7 & $90 \cdot 4$ & $99 \cdot 0$ \\
\hline Diseases of nervous system & $0 \cdot 5$ & 0.3 & $0 \cdot 2$ & $44 \cdot 7$ & $38 \cdot 3$ & $40 \cdot 3$ \\
\hline Diseases of blood & - & - & - & 43.0 & $38 \cdot 5$ & $85 \cdot 0$ \\
\hline Others & 1.5 & $1 \cdot 0$ & 0.4 & $19 \cdot 0$ & $20 \cdot 0$ & $19 \cdot 6$ \\
\hline
\end{tabular}


the duration of the absence, but among diseases which cause frequent absences certain chronic illness are found: alcoholic cirrhosis, psychoses, and neuroses.

\section{Conclusion}

Medically related worker absenteeism is a complex phenomenon involving many factors. This investigation shows that illness is one of them. It is especially by studying the duration of absence that morbidity appears. In effect, one may observe that whatever the index for the duration of absence studied (leave of absence from work or yearly absence) this measure increases with the subject's age and the seriousness of the disorder. Similar observations were noted by Taylor among British Post Office Staff ${ }^{18}$ : the duration of certified sickness absence is higher in groups of people showing other objective evidence of ill health. A study conducted in a large company in Quebec ${ }^{4}$ led to similar conclusions: it showed that the duration of absence, regardless of the specific diagnoses, may be considered as an indicator of future health problems, such as serious occupational accidents or myocardial infarction. These observations suggest that the duration of absence for a sufficiently long period could represent a certain amount of psychophysiological wear for the employees. It could be particularly useful to study the effects on health of modifications in work conditions such as computerisation or work reorganisation, whose medical manifestations could be non-specific. If the relations between absence from work and health status were confirmed and detailed a health indicator could be available, which is interesting insofar as most companies know the durations of absence of individual employees.

The other component of absence, its frequency, seems to be more dependent on demographic, socioeconomic, and occupational factors than on medical factors. For certain illnesses, however-for example, psychiatric disorders - or for certain groups of workers, ${ }^{19}$ it may be valuable as an indicator of health.

The description of absent employees shows, as already pointed out by sociologists and economists, the importance of socioeconomic and cultural factors in the development of absenteeism. As has been already seen, however, the interpretation of the relations observed is not simple. The part played by illness compared with other factors responsible for absence probably differs according to the medical problem. Studies involving particular diagnoses most certainly will enable a better comprehension of the mechanisms concerned here.

From a methodological viewpoint, three aspects of absenteeism must be noted: the time when it occurs, its duration, and its frequency. They are affected differently by the different factors considered. Measures of absenteeism uniting these three parameters as, for example, rates of absenteeism, are thus totally inadequate for an analytical investigation of absenteeism.

For the company and the physicians who are responsible for employee health, these data are essential since they provide indications on the health status of the worker population and on the critical problems that may affect it. Thus in this study trauma, psychiatric disorders, and musculoskeletal diseases appear to be the main health problems.

Medically related absences provide an approach to morbidity that seems to be in accord with the results of surveys of morbidity conducted in France. ${ }^{2021}$ The direct applications for epidemiological studies have obvious limits: diseases such as diabetes or arterial hypertension rarely cause worker disability and are excluded from such an approach. On the contrary, with other diseases - for example, myocardial infarction, or cancers ${ }^{1622}$-it appears to be a good starting off point for epidemiological surveys. It is in this direction that we will continue our research.

\section{References}

1 Thebaud A, Lert F. Absentéisme et santé: une revue critique de la littérature. Sciences Sociales et Santé 1983;2:7-24.

2 Weiss D. L'absentéisme. Revue Française des Affaires Sociales. 1979: Octobre-Décembre: 49-95.

3 Dodier N. L'absentéisme en France: évolution statistique globale depuis 1945. Cashiers du Centre d'Etudes de l'Emploi 1982:25.

4 Dab W, Rochon J, Bernoud L. L'absence au travail comme predicteur de morbidité grave. Une double etude cas-remoins. (Infarctus du myocarde et accidents du travail) dans une grande enterprise Quebecoise. Rev Epidemiol Sante Publique (in press).

5 Finucane RD, McDonagh TJ. Medical information systems roundtable. J Occup Med 1982;24:781-866.

6 Goldberg M, Blanc M, Chastang JF, Blanc C, Sommer M. The health data base of a nationwide company-its use in epidemiological studies. J Occup Med 1982;24:47-52.

7 Monson RR. Occupational epidemiology. Boca Raton, Fla: CRC Press, 1980.

8 Pines A, Sulkeo K, Pollack E, Peritz E, Steif J. Rates of sickness absenteeism among employees of a modern hospital: the role of demographic and occupational factors. $\mathrm{Br} \mathrm{J}$ Ind Med 1985; 42:326-35.

9 Vallin J, Nizard A. La mortalité par état matrimonial-mariage sélection ou mariage protection. Population, numéro spécial 1977:7-121.

10 Desplanques G. L'inégalité sociale devant la mort. Economie et Statistique 1984;132:29-50.

11 Berkman LF, Breslow L. Health and ways of living. The Alameda county study New York: Oxford University Press, 1983.

12 Helsing KJ, Comstock GW, Szklo M. Causes of death in a widowed population. Am J Epidemiol 1982;116:524-32.

13 Luce-Revel D. Etude des facteurs de la disparité régionale des problèmes de santé déclarés à électricité et gaz de France. Thèse Paris VII 1985.

14 Jardillier P, Bauduin H. L'absentéisme: mythes et réalités. Paris: Entreprise Moderne, 1979. 
15 Darbon S. Facteurs de l'absentéisme pour raisons de santé. Lest: ATP-CNRS, 1979.

16 Leclerc A, Aiach P, Philippe A, Vennin M, Cebe D. Morbidité, mortalité et classe sociale. Revue bibliographique portant sur divers aspects de la pathologie et discussion. Rev Epidemiol Santé Publique 1979:27:331-58.

17 Charpak Y. Intérêt et limites de l'utilisation de l'absentéisme comme indicateur de santé: une étude des diagnostics associés aux arrêts de travail dans une grande entreprise mémoire pour le diplôme d'études et de recherches de Biologie Humaine. Université Paris VI: 1984.

18 Taylor PJ. Occupational and regional associations of death, disablement, and sickness absence among Post Office staff
1972. Br J Ind Med 1976;33:230-5.

19 Pell S, d'Alonzo CA. Sickness absenteeism of alcoholics. J Occup Med 1970;12:198-210.

20 Devonassous-Merakehi J, Morel B. Les diagnostics en médecine libérale en 1980. Résultats de l'enquête IDREM Mars 1980-Avril 1981. Santé-Sécurité Sociale Statistiques et Commentaires, 1982:5:5-92.

21 Guidevaux M, Colvez A, Michel E, Halton F. Les malades en médecine libérale. Qui sont-ils? De quoi souffrent-ils? Paris, INSERM, 1975.

22 Friedlander BR, Terry Hearne F, Newman BJ. Mortality, cancer incidence and sickness-absence in photographic processors: an epidemiologic study. J Occup Med 1982;24:605-13.

\section{Vancouver style}

All manuscripts submitted to the $\mathrm{Br} J$ Ind $\mathrm{Med}$ should conform to the uniform requirements for manuscripts submitted to biomedical journals (known as the Vancouver style)

The $\mathrm{Br} J$ Ind Med, together with many other international biomedical journals, has agreed to accept articles prepared in accordance with the Vancouver style. The style (described in full in $\mathrm{Br}$ Med J, 24 February 1979, p 532) is intended to standardise requirements for authors.

References should be numbered consecutively in the order in which they are first mentioned in the text by Arabic numerals above the line on each occasion the reference is cited (Manson ${ }^{1}$ confirmed other reports $\left.{ }^{2-5} \ldots\right)$. In future references to papers submitted to the $\mathrm{Br} J$ Ind Med should include: the names of all authors if there are six or less or, if there are more, the first three followed by $e t$ al; the title of journal articles or book chapters; the titles of journals abbreviated according to the style of Index Medicus; and the first and final page numbers of the article or chapter.

Examples of common forms of references are:

${ }^{1}$ International Steering Committee of Medical Editors. Uniform requirements for manuscripts submitted to biomedical journals. Br Med J 1979;1:532-5.

2 Soter NA, Wasserman SI, Austen KF. Cold urticaria: release into the circulation of histamine and eosino-phil chemotactic factor of anaphylaxis during cold challenge. $N$ Engl J Med 1976;294:687-90.

3 Weinstein L, Swartz MN. Pathogenic properties of invading micro-organisms. In: Sodeman WA Jr, Sodeman WA, eds. Pathologic physiology: mechanisms of disease. Philadelphia: W B Saunders, 1974:457-72. 